\title{
Family Violence and the Criminal Justice System
}

\author{
Arjana Llano \\ PhD Candidate, lecturer at University Ismail Qemali Vlore Albania, \\ Department of Justice Albania, e mail ariana-Ilano@live.com
}

\section{Doi:10.5901/ajis.2013.v2n3p291}

\section{Abstract}

Family violence is becoming a very widespread phenomenon in Albania and the state is taking no preventive measures against such a phenomenon. The Declaration against violence; The Albanian context; The family violence as a criminal offence; Analysis related to family violence court judgments; Conclusions on family violence and Reactions of public authorities. Family violence is prevailing in Albania; yet, police officers, prosecutors, judges and lawyers have not been properly sensitized and trained on family violence issues. No sufficient evidence is being gathered in support of the victims and no psychological support is being given to violated women; furthermore, the extent of punishments is very small and they fail to consider the previous incidents and the continuity of family violence. In most of the cases family violence criminal proceeding depends entirely on women reports, which practically negates the possibility of a fair trial. The methodology, the theoretical and practical methods, the interview methods employed.

Keywords: violence, family, women, girls, men.

\section{Introduction}

Although the most prevailing violation of human rights, violence against women still remains the less considered abusive act. Violence is a serious health problem with injury or death consequences for the abused women. It also infringes their well-being, dignity and self-esteem. There is no cultural or state boundary limit for family violence. Studies carried out on family violence confirm that violence against women is a very complex and multidimensional issue. To explain such a phenomenon, we must consider the cultural, social, family and individual factors that influence on the eventual violence against women.

Violence against women constitutes a violation of the fundamental rights and freedoms of women and it impedes or denies the enjoyment of such rights and freedoms ${ }^{1}$. Violence against women reflects the unequal traditional relations between men and women; it is one of the key social mechanisms to put women under a disadvantageous position. Family violence is a widespread phenomenon in all societies affecting women and girls of all ages irrespective of their position, economic status and social status. However there are some differences related to the efforts of a given state to deal with and reduce violence against women.

The UN Convention on the Elimination of All Forms of Discrimination against Women (CEDAW) was adopted in 1979 and Albania ratified it on 11 May 19942. The Convention defines discrimination against women as "...any distinction, exclusion or restriction made on the basis of sex which has the effect or purpose of impairing or nullifying the recognition, enjoyment or exercise by women, irrespective of their marital status, on a basis of equality of men and women, of human rights and fundamental freedoms in the political, economic, social, cultural, civil or any other field." The Convention entered in force in lesser time than any other convention adopted by the UN and it was the one to have been provided with more reservations. It means that the member states are entitled to disrespect one or more provisions. Some states enter a reservation on article 2 (which condemns discrimination), although their national constitution or laws prohibit discrimination. It means that human rights of women and girls are not yet considered and believed as equal to the human

\footnotetext{
1 The term "family violence" is narrowly defined as violence or threats exercised by the male spouse or former male spouse against his wife or former wife. This narrow definition leaves no room for other forms of domestic violence, such as child or other family members abuse and other violent acts as may be the violation of property and economic rights.

${ }^{2}$ The UN Convention on the Elimination of All Forms of Discrimination against Women (CEDAW) was adopted by the General Assembly of the United Nations on 18 December 1979 and entered in force on 03 September 1981, see http://www.un.org/womenwatch /daw/cedaw/text/econvention
} 
rights of men. To be noted is that the Convention itself fails to mention gender based violence or family violence, as they would not have been accepted by many states. Today, after 27 years, there is not a mandatory international document to recognize the family violence as an integral part of the discrimination against women and of the infringement of some fundamental human rights such as the right to life and human dignity and the right to freedom from torture and degrading treatment.

\section{Declaration against Violence}

The declaration defines "violence against women" as: "any act of gender-based violence that results in, or is likely to result in, physical, sexual or psychological harm or suffering to women, including threats of such acts, coercion or arbitrary deprivation of liberty, whether occurring in public or in private life"3.

The declaration provides,

Violence against women shall be understood to encompass, but not be limited to, the following:

a. Physical, sexual and psychological violence occurring in the family, including battering, sexual abuse of female children in the household, dowry-related violence, marital rape, female genital mutilation and other traditional practices harmful to women, non-spousal violence and violence related to exploitation;

b. Physical, sexual and psychological violence occurring within the general community, including rape, sexual abuse, sexual harassment and intimidation at work, in educational institutions and elsewhere, trafficking in women and forced prostitution;

c. Physical, sexual and psychological violence perpetrated or condoned by the State, wherever it occurs.

Article 3

Women are entitled to the equal enjoyment and protection of all human rights and fundamental freedoms in the political, economic, social, cultural, civil or any other field. These rights include, inter alia:

a. The right to life;

b. The right to equality;

c. The right to liberty and security of person;

d. The right to equal protection under the law;

e. The right to be free from all forms of discrimination;

f. The right to the highest standard attainable of physical and mental health;

g. The right to just and favorable conditions of work;

h. The right not to be subjected to torture, or other cruel, inhuman or degrading treatment or punishment.

Article 4

States should condemn violence against women and should not invoke any custom, tradition or religious consideration to avoid their obligations with respect to its elimination. States should pursue by all appropriate means and without delay a policy of eliminating violence against women and, to this end, should:

... (c) Exercise due diligence to prevent, investigate and, in accordance with national legislation, punish acts of violence against women, whether those acts are perpetrated by the State or by private persons;

(d) Develop penal, civil, labor and administrative sanctions in domestic legislation to punish and redress the wrongs caused to women who are subjected to violence; women who are subjected to violence should be provided with access to the mechanisms of justice and, as provided for by national legislation, to just and effective remedies for the harm that they have suffered; States should also inform women of their rights in seeking redress through such mechanisms;

... (h) Include in government budgets adequate resources for their activities related to the elimination of violence against women;

(i) Take measures to ensure that law enforcement officers and public officials responsible for implementing policies to prevent, investigate and punish violence against women receive training to sensitize them to the needs of women;

\section{The Albanian Context}

Thousands of women in Albania are at risk of violence from their husbands or intimate partners. They are hit, beaten,

\footnotetext{
${ }^{3}$ Declaration on the Elimination of Violence against Women, article 2.
} 
raped, and in some cases even killed ${ }^{4}$. Many more endure psychological violence, physical and economic control. Some barriers exist that prevent women from seeking help from the competent authorities, including the justification of violence with the "Albanian traditions", the incapacity of competent authorities to respond to women that seek help, and the incapacity of the legal system and the judiciary to acknowledge domestic violence against women (family violence) as a criminal offence.

Albanian and other countries of the Balkans have an average rate of family violence, which means that approximately $30 \%$ of women percept themselves as victims of family violence ${ }^{5}$. Whereas the rate of domestic violence of a country is extremely important, the way this country deals with the domestic violence is still more important, i.e. what are the chances for a domestically violated woman to find appropriate protection and solution against domestic violence and to what extent are the abusers punished? In Albania there is still a lot to be done on this issue.

In Albania there are a small number of criminal cases for family violence and this may be due to different reasons; however, it seems like everything originates from the patriarchal mentality that dominates in the Albanian society. A good strategy to fight such a mentality would be that the lawmakers and the Albanian authorities keep a clear stance against the undesirable expressions of this mentality - family violence included - by adopting appropriate strategies aimed at solving these problems.

\section{Interviewing Abused Women}

During the interview, the abused women state to have been slapped, punched, kicked, thrown against the wall or other house furniture, dragged inside the house, took out of the house, pulled by their hair, broken their arms and teeth, extinguished cigarettes on their bodies, put a gun to their head, raped and threatened with knives and grenades. A 31year old married woman and mother of three children tells us her story: "He always used to beat me, but I remember one day when he hit me more than ever. That day he came late at night and totally drunk. He started to beat me and I couldn't understand why. He grasped a bottle and broke it on my head. I started to bleed. I couldn't move. Then he pulled me by my hair, took me out of the house and left me there. A neighbor helped me. She kept me in her house". Another 44-year woman states: "He started to abuse me since the first days of our marriage and for the last 25 years... He threatened me to death. He always kicked me or pierced me with scissors, fork etc. I blame alcohol for the behavior of my husband; indeed he drank too much. However, he is violent even when not drunk". A 46-year divorced woman and mother of two children tells us another story of physical violence: "Once he extinguished his cigarette on my body. He used to break my bones but I didn't go to the hospital".

Many acts of physical violence consist in lacerations, torsions and fractures. An unemployed woman from Tirana tells: "He came home and beat me without any reason. Some times his brothers have taken me to the hospital for I had fractures. After an hour he would calm down and ask for my forgiveness. For a month he would treat me nicely, but afterwards he would become violent again".

Often, physical violence comprises that kind of controlling behavior aimed at monitoring every move of the woman. Disobedience to the traditional gender roles and expectations, including the doubt of adultery, is likely to result in physical violence. A 31-year female teacher and mother of two children tells: "My daughter was just one-month old when he came home one night and started with his presumptions: "you have been out today and see him", whereas I had been home all day. Nevertheless he started to kick me. I had my daughter in my arms and I tried to save her from being harmed. Later one such violent episodes became more frequent. Almost every night he used to come home totally drunk. The last time he abused me was when I was pregnant with my second child. He hit me as hard as a man can hit. He was drunk again. The next morning, when I woke up I couldn't recognize my self in the mirror. My face was full of scratches.

\section{Family Violence as a Criminal Offence - Analysis}

The systematic and recurrent nature of family violence. In many marriages family violence is a recurring phenomenon and wives are likely to suffer abuse every month, week, day or even every hour. A criminally proceeded and judicially

\footnotetext{
${ }^{4}$ Amnesty International, Albania: Domestic violence against women: "It is not her shame" (London, 30 March 2006) [AL Index: EUR 11/002/2006] http://web.amnesty.org/library/index/ENGEUR110022006.

5 See an article published in British Medical Journal of 20 July 2005, "Spousal Violence Affects One in Three Albanian Wives", http://www.newswise.com/articles/view/513263/
} 
tried act of abuse is probably the last of an infinite series of violent acts (sometimes a hundred of such acts) of husbands against their wives. While such a violent act can be easily identified on time by the victim, the particularities of such act and the distinction between this act and other incidents can hardly be indicated by the traumatized victim. Moreover, the regular and systematic nature of the abusive acts is likely to cause a more serious impairment of the violated woman's personality and self-esteem than it is evident in the act itself. However, in the case of multiple criminal offences they are normally punished separately and the recidivism is an aggravating circumstance. Criminal offences related to family violence such as threatening, intentional slight injury or other intentional injuries, pursuant to the Albanian criminal code have a minor criminal value and systematic attacks against women's personality and self-esteem are less likely to be charged with the appropriate punishment. In 1998 the penal code of Sweden provided a special criminal offence related to domestic violence. Chapter 4, section 4a of Swedish penal code ${ }^{6}$ provides: "A person who commits criminal acts as defined in Chapters 3, 4, or against another person having, or have had, a close relationship to the perpetrator shall, if the acts form a part of part of an element in a repeated violation of that person's integrity and faulted to severely damage that person's self-confidence, be sentences for gross violation of integrity to imprisonment for at least six months and at most six years.

If the acts described in the first paragraph were committed by a man against a woman to whom he is, or has been, married or with whom he is, or has been cohabiting under circumstances comparable to marriage, he shall be sentenced for gross violation of a woman's integrity to the same punishment.

\section{Analysis of Court Judgments Related to Family Violence}

Judgment no. $8^{7}$ - The defendant was charged with threatening his wife and sentenced to imprisonment equal to the period of custody, i.e. three months and 24 days. According to this judgment, the defendant had punched and kicked his ex-wife until the neighbors' intervention.

Comment: considering this judgment, we find uncertain the source of information about the injury; however it's worth mentioning that the defendant was not charged with injury pursuant to section 89 or 90 of the criminal code.

Judgment no. 27 - The case is about a 20 years old woman, LL, who had killed her husband. LL was charged with the criminal offence of murder under heavy psychical shock and of illicit detention of weapons. During the trial LL was assisted by a lawyer. The judicial investigation showed that LL had been abused physically and psychically on regular basis since the first hours of her marriage, and due to such abuse, in 2001 she had entered a psychiatric hospital. On 22 June 2003 her husband had mistreated her brutally for being pregnant. Then he had taken an automatic weapon and threatened her to death. He had crashed her on the bad and ordered her to undress. At this moment LL had noticed that the weapon was close to her. So she had taken it and shot her husband dead. In determining the sentence, the court considered the difficult economic situation of $\mathrm{LL}$, the place where the crime was committed and the circumstances that had led to the commitment of the criminal offence. The court accepted the abbreviated trail and finally sentenced the defendant to three years of imprisonment. The sentence was not appealed.

Comment: It is evident that after mistreating and threatening LL, her husband intended to rape her. In this case LL acted for self-defense and therefore she is bears no penal responsibility ${ }^{8}$. Although the court did not question the reliability of LL, there is no doubt that LL was compelled to protect herself from the continuous and serious attacks to her physical integrity. Even though it is the duty of the lawyer to describe the actions of $L L$ as self-defense actions under the given circumstances, the prosecutor and the judge should make sure that LL was not charged with something for which she bears no penal responsibility pursuant to the criminal code.

\section{Conclusions}

It is estimated that the family violence affects approximately 30 percent of the Albanian women; however such a percentage is not reflected in the number of sentences given for the criminal offences of domestic violence. Family

\footnotetext{
${ }^{6}$ The Penal Code of Sweden in English: http://www.sweden.gov.se/content/1/c6/02/77/77/cb79a8a3.pdf

${ }^{7}$ Court judgments on family violence

${ }^{8}$ Criminal Code, Chapter 19, section 1: Necessary defense. A person bears no criminal responsibility if he commits the act while being compelled to protect his or somebody else's life, health, rights and interests from an unfair, real and accidental attack, provided that the defense is proportionate to the dangerousness of the attack. Obvious disproportion between them constitutes excessiveness over the limits of necessary defense.
} 
violence still remains an offence not properly reported, investigated, tried and sentenced. In other words, most of the offenders have their impunity guaranteed, although there have been made some amendments and offered a kind of support to women suffering the abuse of their husbands or intimate partners. Unreported family violence is a consequence of the patriarchal traditions, lack of sensitization and often the weak position of women in the Albanian society. Women asking for compensation take little or no support from the competent authorities; they are even accused by the society for destroying their families. Inappropriate criminal proceedings and insignificant punishments are a consequence of many factors. Frequently family violence is considered as an irrelevant issued to be better solved within the concerned family. Family is considered more important than the physical or mental integrity of the woman as an individual. Police officers, prosecutors, judges and lawyers have not been properly sensitized and trained on family violence issues. No sufficient evidence is being gathered in support of the victims and no psychological support is being given to violated women; furthermore, the extent of punishments is very small and they fail to consider the previous incidents and the continuity of family violence. In most of the cases family violence criminal proceeding depends entirely on women reports, which practically negates the possibility of a fair trial. Sentences provided by the criminal code for family violence issues are lower than sentences for other heavier criminal offences. Neither the sentences, nor the aggravating circumstance provided by the criminal code consider the recurring nature of the family violence and the fact that the victim may have suffered for a long period the abuses of her husband. Therefore, it is necessary that many debates and sensitization campaigns are held for the purpose of creating the appropriate space to the undertaking of common actions. Such sensitization campaigns should be directed to the general public, special communities, family members etc.

It is important that the situation of violence against women be considered at a national level for the purpose if identifying the reasons of such a violence and making efficient interventions.

The public and private authorities should be encouraged to support women independence.

\section{References}

Konventa e Kombeve të Bashkuara mbi Eliminimin e të Gjitha Formave të diskriminimit ndaj Grave viti 2005 deklarata mbi Eliminimin e dhunës ndaj Grave viti 2007

Revistën Britanike Mjekësore British Medical Journal viti 2010

Kodi penal i Suedisë viti 2000

Vendime gjyqesore te lidhura me dhunen ne familje

OSCE. Raporti mbi të drejtat e njeriut 2010 Shqipëri

USAID. Udhëzimet për Urdhrat e Mbrojtjes në Shqipëri. 2006

USAID. Protokolli shëndetësor në Shqipëri për dhunën në familje. 2006

Qendra "Fëmijët Sot". Manual trajnimi "Dhuna në familje ndaj fëmijëve, sistemi i mbrojtjes së fëmijëve". Tiranë, 2009

UNICEF. Dhuna ndaj fëmijëve në Shqipëri. Tiranë, 2006

Kodi Penal I Republikes se shqiperise

Amnesty International. Raport 2011: Situata e drejtave të njeriut në botë (Shqipëria) 
